\title{
「波動歯車装置を内在する位置決め機構に対する高速高精度制御系設計の研究と 製品開発」にまつわる話
}

\author{
名古屋工業大学 岩崎 誠 (株)ハーモニック・ドライブ・システムズ 山元純文，沖津良史
}

1. は じめに

波動歯車装置を内在した位置決め機 構を有するさまざまな産業用機器に は, 一般に高い加工生産性や高精度性 が要求されるため, 各種非線形要素の 補償，機構振動の抑制，機械設置環 境・製品個体差や経年・経時変化によ る特性変動や外乱に対するロバスト性 能を具備した高速高精度制御系の構築 が必須である，本研究開発による製品 実用化に際しては，モータ・ドライバ の高トルク化や小型化の実現のみなら ず，精密モデルベースのフィードフォ ワード（以下, $\mathrm{FF}$ ) 補償や適応・ロ バス卜制御によって, 多様な要求制御 仕様の満足を目指している。 さらに, オートチューニング機能を導入するこ とで, サーボパラメー夕調整に対する 省力化と調整者間のばらつき低減, 操 作性・メンテナンス性の向上なども実 現させている（具体的な研究開発項目 は, グラビアページの図 1 を参照され たい).

ここでは, 本研究開発に至る精密位 置決め制御に関する筆者の想いと, 精 密位置決めを実現する制御技術の展開 について紹介したい.

\section{2. 精密位置決めとの出会い}

筆者の岩崎は, 大学院の研究テーマ として誘導電動機のベクトル制御，す なわち「パワーエレクトロニクス」 「モータ制御」を選び, その後大学に 奉職するころから「メカトロニクス」 「運動制御」に教育・研究の軸足を置 いてきた，そのため，主に電気学会を 活動の場としてきたが, 当時の講演会 や技術委員会では, 外乱推定と補償, 共振振動系のモデル化と制振制御な
ど，ロバスト制御や適応制御などの制 御工学に基づくフィードバック（以 下，FB）制御による手法が多く議論 されていた，そんな折に，精密工学会 の講習会（第 180 回講習会「最近の精 密位置決め技術」平成 3 年 11 月 15 日）を受講する機会を得た。それまで は，上述のように FB 制御ありきで運 動制御系を捉えていた筆者にとって, 講習会のメニューで初めて出会った位 置決め要素技術は機械・機構の学理に 即したもので, 電気工学を学んできた 者にとって極めて新鮮であった，中で も, 後の精密位置決めに関する研究活 動に影響を与えてくれたキーワードと して,「粗微動位置決め」「ボールねじ 微小変位特性」「パワースペクトラム 分布によるコマンドシェーピング（以 下，CS)」が挙げられ，特にモデルベ 一スの FF 制御や CS には, 機構振動 と制振に対する物理的な原理原則を見 て, 大きな可能性を感じた。 そこで, モデルマッチング FF 補償器設計や, 共振フィルタ併用による加減速時間に 着目したCSなどに取り組んだ，その ころの想いはその後の研究に続き, 既 約分解表現や終端状態制御などを併用 した 2 自由度制御系の設計, 外乱・摩 擦補償, 切り替元制御や初期值補償, モデル化や最適化などを深く追求する こととなった。

そうこうしているうちに，再び講習 会（第 218 回講習会「これからの精密 位置決め技術」平成 7 年 10 月 17 日) を受講した。 その中で，電子部品実装 機に関わる高速高精度位置決め制御の 具体的なスペックを张聴し，驚愕し た、それは，「どう考えても FB 制御 带域では整定時間の達成は無理」と考 えざるを得ないものであった，そこ
で,

・応答性は FFで，ロバスト安定性は $\mathrm{FB}$ で (至極当たり前), FF は CS も含めていろいろなアプローチがあ りそうだ，モード切り替えで整定性 を良くしよう, 初期值の問題も解決 しなければ,

·FFにしてもFBにしても, 設計に 精密モデルが要るだろう, モデル化 技術（線形・非線形要素）を極める ことが肝要だ，そこではいろいろな 最適化技術が適用可能だろう,

・モデル化誤差や環境・経時変化が $\mathrm{FF}$ 特性を劣化させてしまうから， 適応的に対応させよう, オートチュ ーニング機能も有望だろう，

・振動を抑制しながら位置決めさせる 必要があるから，共振周波数成分を 落としながら, 指定の時間で到達す るCSを考えよう, さらに制振しや すい機構系もありそうだから設計に つなげよう,

こんな想いを悶々と巡らせ続けなが ら, 次章で紹介する制御技術を, 減速 機, 電子部品加工機, 半導体 · 液晶製 造用ステージ, 産業用ロボット, 自動 車部品などさまざまなメーカとの産学 連携共同研究を推進しながら開発して いった。

\section{3. 精密位置決め制御と要素技術}

位置決め制御系設計の研究を進める 中で, 超精密位置決めに打けるアンケ 一ト調查（『精密工学会誌』2008 年 10 月号）を张見した，そこでは，“超精 密位置決めとは?”の問いや, 超精密 の理由や限界要因分析, 多様で変化に 富む位置決め要求仕様などに言及され ていた。これらの要求や仕様に対し, 機械がもつ運動精度能力を限界まで引 
き出してさらなる高速高精度性を追求 し, かつ設置環境条件や外力にも左右 されない超精密位置決めを実現するた めには,「機械構造体＋センサ+制御」 を統合したシステムとして，“制御技 術との合わせ技が必須である”とのこ とだった。これらは，現在でも十分通 用する課題とアプローチであろう。

それでは，与えられた機械システム （制御対象）がもつ運動精度を最大限 引き出すために, 位置決め制御技術が 提供すべき点は何であろうか？ それ は，前述の課題を大まかに集約して， 「高速高精度かつ外乱や機構変動に口 バストな位置決め制御系を構築する」 ことであり, 制御工学の観点からは $\lceil\mathrm{FB}$ 制御ゲインを大きく選んで応答 带域を拡大する」ことが本質である。 しかし，機構振動や制御系のむだ時間 などの阻害要因がシステムの不安定化 や精度劣化を引き起こすため, 応答帯 域拡大の実現は一般に容易でない。そ れを可能とするアプローチの一つに， 制御対象の特性を積極的に利用した $\mathrm{FF}$ 制御を付加する「2 自由度制御系」 の導入が挙げられる。

図 1 は, 本研究開発で扱った波動 歯車装置を内在する位置決め機構をは じめ，筆者がさまざまなメカトロニク ス機器の位置決め制御系に適用してき た 2 自由度制御系の構成図で, 各コン ポーネントの役割・効果を併記したも のである ${ }^{1)}$. 2 自由度制御は, センサ 情報を使った $\mathrm{FB}$ 制御によりシステム の安定化やロバスト化を図り, FF 制 御によって高速応答性を担保するもの である。 その結果, 機構振動の抑制, 外乱の抑圧, 機構や環境変動の影響を 排除，応答のばらつき抑制による位置 決め精度の平準化など，前述の課題を 幅広く解決して所望の位置決め仕様を 満足可能とする。この制御系の設計に 際して極めて重要な準備は, 機構や外 乱を含む制御対象の精密モデル（高精 度シミュレー夕）を獲得することであ る。本研究開発では, 波動歯車装置に 固有の摩擦・ばね特性・角度伝達誤差 を含む線形・非線形要素に対する精密 モデル・シミュレータの構築が, 所望 の制御仕様を満足する位置決め制御系

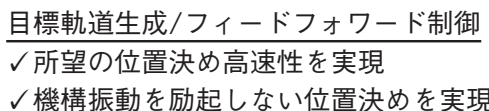

制御対象・外乱の高精度モデリング $\checkmark$ 機構や外乱を含む高精度シミュレータの構築 $\checkmark$ 環境外乱の影響を有効に抑圧可能 $\checkmark$ 機構の特徵を生かした高度な制御系を設計

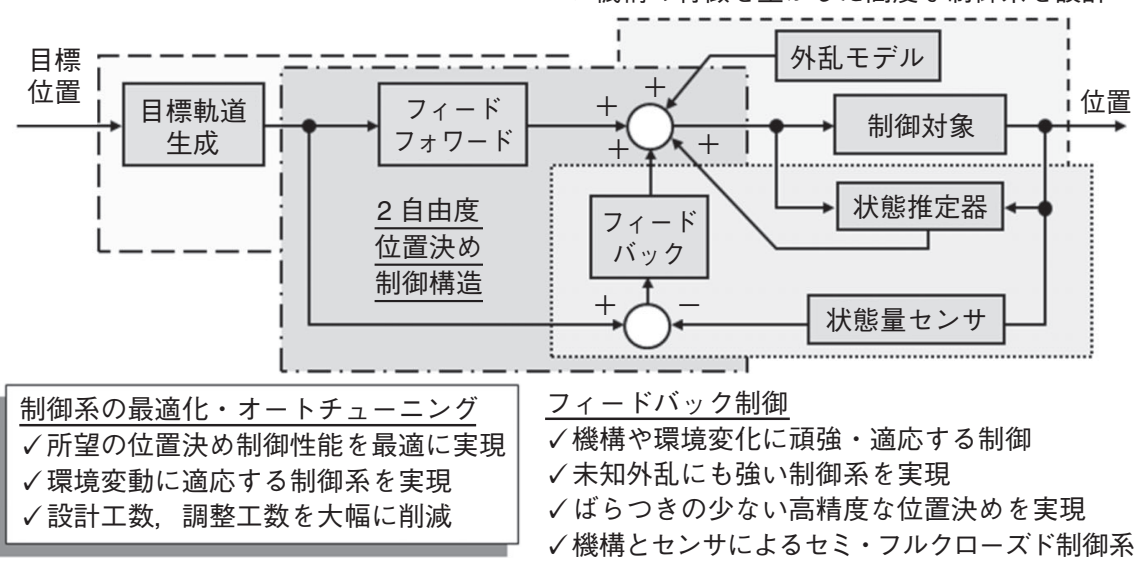

図 1 高速高精度位置決めを実現する 2 自由度制御系の構成概念とその目的

設計において極めて重要であった。そ のような対象機器に対する精密モデル を用いれば, 稼働部重量や姿勢の変 化，周囲温度変動，経年変化，製品間 特性ばらつきや，設置床面など周囲環 境からの外乱に対して，ロバストまた は適応可能な FB 制御を制御工学に即 して設計可能である。一方，所望の目 標位置に対する CS F FF 制御は，精 密モデルを積極的に利用することで所 望の高速性を保証し，かつ機構振動を 励起しない高精度な位置決めを実現す る、筆者らの研究では, 駆動アクチュ エータの制約（トルクや推力制限な ど), 設置床面との連成振動, 摩擦な どの外乱の影響，駆動音などを最小限 のレベルに抑えるロバストな目標軌道 生成法を開発し，さまざまな実製品へ の搭載も検討してきた。この軌道生成 法はさらに,「所望の位置決め性能を 達成するために, 最適な機械構造はど うあるべきか? 」を提示する発展性も 秘めている。

\section{4. おわりに}

わが国の精密加工機械は，その精 度, 生産性, 信頼性共に現在世界卜ッ プレベルにあることは間違いないが, 一方で, 後発の新興国メーカの競争力 アップも目覚ましい。今後も現状の地 位を維持するためにも, 高付加価值か つ低価格な製品の開発によるさらなる 競争力向上が望まれよう。位置決め制
御技術に対するソリューションとして は, 制御系の最適化やオートチューニ ング技術が実用性の観点からも有望で ある、筆者らは以前より, 適応同定理 論や遺伝的アルゴリズムなどを適用し たオートチューニング技術を開発し， 前述の精密モデリング，制御系設計と 制御パラメー夕の調整などを, 工場出 荷時や機械設置現場で自動的に行い, 設計工数や調整工数の大幅な削減を実 現してきた，これらの技術は，省力化 や製品・製造コスト減にダイレクトに つながり, 競争力の高い製品づくりに 大きく寄与するものである

\section{謝辞}

本技術に関わる研究および製品開発 は, 長期かつ密な産学連携共同研究活 動による，実践的な産業応用に資する ものです. 研究に携わった大学研究室 の歴代学生や多くの会社関係者にご尽 力をいただきました。一方，本文中で 紹介した精密工学会の講習会などは, 筆者の研究活動に大きなインパクトを 与えていただき，その資料を事あるご とにバイブルのごとく扯見していま す。この場を扮借りして樑く感謝申し 上げます。

\section{参 考 文 献}

1) M. Iwasaki et al.: IEEE Industrial Electronics Magazine, 6, 1 (2012) 32-40. 